\title{
The Development of Comprehensive Guidance and Counseling Program Model
}

\author{
Miswatul Mughiroh, Retno Tri Hariastuti, Najlatun Naqiyah \\ State University of Surabaya \\ Surabaya,Indonesia \\ mizwa.mahkotaq@gmail.com
}

\begin{abstract}
The aim of this research was to design and develop comprehensive guidance and counseling program covering the competency standard of personal, social as well as study and career field. This research used Research and Development ( $R \&$ D) method. The population in this study were 450 students in Junior high school of 2017-2018 academic year. The data were collected through questionnaires, interviews, and observations. The results of the study concluded that guidance and counseling teachers had not yet comprehensively comprehended the preparation of comprehensive guidance and counseling programs. Dealing with the guidance and counseling done by teachers, it required an overview of the development program model in order to facilitate teachers dealing with guidance and counseling in implementing the program and providing services for the students. A comprehensive guidance and counseling program model were developed to meet the school needs and conditions.
\end{abstract}

\section{Keywords-development, Comprehensive Guidance and} Counseling program model

\section{INTRODUCTION}

Guidance and counseling are provisions of assistance for students, which aims at assisting students in the introduction of potential, needs and developmental tasks as well as meeting the needs and tasks dealing with the student's development. In providing services for students, guidance and counseling are not only for students who have problems, but for all students who need to be given guidance with the hope of fulfilling the needs so that it can run optimally. To follow up the above thoughts, guidance and counseling focused on identifying the needs of learners, parents and schools.

The important roles ofguidance and counseling in helping learners achieve developmental tasks are listed in the Standards of Student Self-Reliance Competence developed by ABKIN. To support the achievement of the optimum student developmental tasks, a comprehensive counseling and counseling program with the collaboration of all school stakeholders was established.

A guidance program is a guide in carrying out tasks or activities that will be done in the implementation and it is flexible. According to [1] guidance program is a series of planned, organized and coordinated guidance activities during a certain period.
The Comprehensive Guidance and Counseling Program [2] is a central component within a school's learning environment. It provides the integration of guidance and counseling services into a comprehensive model that croses the curicula to address student needs through well-defined outcomes (Journal Comprehensive Guidance and Counseling program).

The components of the program are guidance curiculum, counseling, consultation and coordination, life and career planning, program management and support system.

The program aims at providing a structure to help the program to meet the guidance and counseling needs of all student, help students understand themselves, build meaningful relationships with others, help student plan and achieve educational goals and explore personal career pats, provide consultation and coordination services to educator, parent, administrators, and others who work with students, etc.

In a comprehensive guidance and counseling program the goals and objectives are formulated based on the identification of the needs of the students, parents and teachers through an accurate study so that what the counselor does, is not a fabricated activity but it is based on empirical data.

Based on the empirical data conducted at Zainuddin Junior High School, the development of the program was done according to the needs of the students without adjusting to the assessment result so that the delivery of the student service was less than the maximum it could reach. The program was be developed based on the results of the questionnaires fulfilled by students in Junior High School through the POP guidance and counseling instrument with the result of the significance between the private field (total $1174=44.30 \%$ ), social (total $575=21.70 \%$ ), study (total 490 $=18.49 \%$ ) and career (total $411=15.51 \%$ ). The purpose of the dissemination of the instrument was to determine the needs and problems of the students who would be included in the development of comprehensive guidance and counseling programs in Junior high school.

Along with the development of the guidance and counseling, the development of comprehensive guidance and counseling program began to be widely discussed in scientific forum and supported by the Minister of National 
Education No 27 Year 2008 stating that the guidance and counseling program in Indonesia leads to a comprehensive approach. This approach concerns with the guidance and counseling teachers in providing services at schools. In 2003 , the program was already implemented but not all schools used the comprehensive guidance and counseling program. Comprehensive counseling is able to make a positive contribution to the academic, personal, social, and career development of students in schools. Comprehensive guidance and counseling program is also able to create a conducive learning climate for the students at schools. Looking at Minister of National Education No 27 of 2008, it is stated that counselors are directed to develop comprehensive guidance and counseling programs, but some guidance and counseling teachers have not fully understood how to design a comprehensive guidance and counseling program.

The results of research conducted at Junior high school level, while following MGBK Sidoarjo, obtained the data through interviews that some guidance and counseling teachers have not comprehended guidance and counseling Comprehensive and not yet apply it in school. It is supported by the questionnaire dispatch containing a number of questions about Comprehensive Compilation Programming Competencies which obtained result $75 \%$ of the guidance and counseling teachers have not comprehensively comprehended the basic concept of compilation of Comprehensive Guidance and Counseling program. Meanwhile, $25 \%$ of guidance and counseling teachers have already understood the program holistically and have applied it in their school.

Based on the explanation above, the researcher was interested to design the model of comprehensive guidance and counseling program in Junior high school. Such program is important because it can assist the counselors in providing services for the students according to their needs.

\section{METHOD}

This research is a development research using developmental research design model proposed by Borg \& Gall. The procedural model is descriptive with the steps followed to produce the product, as is the research and development cycle [3]. The research development approach is limited to stage 1-7 including: 1) research and information gathering stage, 2) product planning and design stage, 3) initial product development stage, 4) expert validation test, 5) product revision, 6) field test by user, 7) revision of the final product.

The research began with the information gathered through preliminary studies which found out the level of counselor's need for comprehensive Counseling and Counseling programs. The development stage included formulating the design of student and environmental assessment needs, comprehensive guidance and counseling program model and guidance validated by experts as well as Focus Group Discussion (FGD), evangelization and improvement, and finalized models that have been validated.
This research used various techniques comprising interview, observation and questionnaire. Interviews and observations were used to find out the school's visibility in the implementation of comprehensive guidance and counseling programs. Meanwhile, questionnaires were used to gain an overview of the needs and understanding of comprehensive counseling and guidance programs. In the development phase of the Comprehensive guidance and counseling program model, questionnaires and assessment scales were used as the data collection techniques for revealing the students' needs, principals, school steamers and parents. The scoring scale was used for expert in testing the assessment need design and the comprehensive guidance and counseling program model. The data were analyzed using descriptive statistic that was analytical technique in order to analyze data by describing the collected data as it is without intending to make conclusion to be shown publicly or making generalization [4]). The interviews with the guidance and counseling teachers to describe the school visibility dealing with the implementation of comprehensive guidance and counseling programs. Quantitative data analysis was done through quantitative descriptive analysis that was to analyze quantitative data obtained from the questionnaire evaluation sheet obtained from expert validation and to analyze the questionnaire of students' requirements.

\section{RESULTS AND DISCUSSION}

From preliminary study, through questionnaires given to the guidance and counseling teachers in Waru Sidoarjo, it was obtained that there was a significant result with percentage of $75 \%$ dealing with comprehensive guidance and counseling which had compiled 15 statements from the basic concept of comprehensive guidance and counseling. In the implementation of comprehensive guidance and counseling programs, it was important to know the visibility of the implementation of comprehensive guidance and counseling program. Visibility is a supportive resource in the implementation of a comprehensive counseling and counseling program.

At this stage, to develop the initial program based on operational guidance and counseling in junior high school, the structure of development of comprehensive guidance and counseling program that will be developed are explained as follows:

1. Annual Program: Rational, legal basis, mission vision, needs description, requirement formulation, program component, service area, friend or topic development, activity plan, evaluation plan, infrastructure, and expense.

2. Semester Program: odd semester program, even semester program, RPL guidance and counseling (classical, large class / cross class, group, individual). 
Table 1 Visibility of Program Comprehensive Guidance And Counseling Program Implementation

Criteria of Comprehensive Guidance and Counseling program Implementation

School's Readiness in Implementing Comprehensive Guidance and Counseling Program

Educators guidance and counseling

1. Develop a description of the task of the counselor

2. Determine tasks, roles and responsibilities in the comprehensive guidance and counseling program 3. Develop descriptions of the tasks involved in the comprehensive guidance and counseling program 4. Establish optimal cooperation

1. The school counselor at Zainuddin Junior High School consisted of two guidance and counseling The ideal number of counselors was 1: 150 with background education in guidance and Counseling. Besides, the guidance and counseling teachers had become professional educators when they had educator certificates. teachers with 450 students.

2. Description of the task counselor with class division and class entry time.

Financial resources

1. Setting a budget for each year

2. Determine the required facilities for guidance and counseling

3. Explore the use of offschool resources

4. Evaluate the implementation of comprehensive guidance and counseling programs

School policies / rules

1.Evaluate policies and procedures each year

2. Work with school staff

3. Work with parents and students concerned

Comprehensive guidance and counseling programs are based on the achievement of developmental tasks, potential development, and the eradication of counselee problems. The standard of competence of students used in Indonesia refers to the Standards of Student Self-Reliance Competence which is listed in 11 aspects of development. The objective of program development was to design and develop a comprehensive guidance and counseling program covering standards of competency and indicators of personal, social, learning and career competencies. The purpose of comprehensive guidance and counseling program in a systematic way was to overcome the gap between the standard of competence that students needed to be achieved and their ability in school or in certain areas.

The development of standard of competence for the students in Indonesia is not the same as other countries including in America. For the standard of student competence in Indonesia, it is adjusted to the needs and problems to be given intervention. The results of literature study and adaptation of standard of competence development from a book dealing with South Carolina Comprehensive Development Guidance and Counseling Program Model [5], it can be concluded there are four areas of development covering

1. Personal Development

a. Understand and accept self-potential as well as empower and develop their potential

b. Understand talents and interests possessed and have a positive wish for the future

c. Have self-motivation and desire to develop selfreliance behavior

2. Social Development

a. Have sensitivity to the surrounding environment and develop skills utilizing around condition

b. Have communication skills to build positive interpersonal relationships

3. Learning Development

a. Acquire knowledge, skills and attitudes as an active learner's contribution

b. Use strategies to achieve success in achievement

c. Understand academic correlation with life in school, home and neighborhood

4. Career Development

a. Understand entrepreneurial character

b. Recognize the values of frugal and cooperative behavior in everyday life

c. Understand interpersonal relationships, education and the workplace

d. Able to make decisions, determine goals and solve problems as well as have communication skills

e. Explore career and school correlation for work

f. Demonstrate a positive work-related talent and the ability to work together.

The preparation of comprehensive guidance and counseling programs was prepared based on the needs of students whose data were obtained from student questionnaires, principals, school stakeholder, and parents. The initial draft questionnaire that had been prepared matched the agreed model of the questionnaire. The questionnaires have been developed with the standard of student competence which became the basis of the development of the questionnaire grid. The questionnaire developed was given four choices of option including: SS: 
Very Match, TS: Not Suitable, S: Suitable, STS: Very Unsuitable. The questionnaires for the principals, teachers, school and parent stakeholders had 3 choices of answers including very important, important and not important. The use of questionnaires for students and the environment staffs (parents, school principals, and school stakeharies) were aimed at facilitating analysis for assessment results.

Comprehensive Guidance and counseling program model in another research [6] showed that the reseacher developed the firsh program based on program development structure of comprehensive guidance and counseling program developed by ASCA [7] as the followings:

Section 1 Foundation : Rationale, Development Area, Need Description.

Section 2 Delivery System : Curriculum Guidance, Responsive Service, Individual Planning, Support System.

Section 3 Management System : Agreements, Advisory Council, Use of Data, Use of Time, Calender.

Section 4 Accountability : Result Repot, School Counselor Performance Standart, The Program Audit.

This program model needed adaption with the culture of Indonesia dealing with the standart of students' competence and the need of asessment dealing with the arrangement of such comprehensive guidance and counseling program.

For comparison, in America, the standards of competece for the students are divided into three fields (domains) embracing academic, personal / social, and career (ASCA). Meanwhile, Florida (2010) put forward the four areas of development (domain) namely academic, career, personal, social, and involvement in the community as well as Global Citizenship Development. Meanwhile, in Utah [8], (Gysbers, 2012) the development the standard of competence deals with four fields namely academic or learning development, career development, development of multicultural / global citizens, and development of social person.

\section{CONCLUSION}

The model of comprehensive counseling guidance used the Borg \& Gall's R \& D model development procedure, but in this study, the phase was limited to the Research and development phase of the hypothetical model development phase. Within this limitation, the program model that had been developed needed to be conducted in a limited trial in order to obtain a comprehensive model of counseling and comprehensive counseling program.

The standards of competence that been developed were based on Standards of Student Self-Reliance Competence which were listed in 11 aspects of development. Dealing with the inputs, they covered the opinions from reviewer and field test by user in the Waru Sidoarjo so that the development of student competency standards will be generalized to be ideal for Indonesian students and Implementation of comprehensive guidance and counseling program and will be generalized throughout the school. The effectiveness of the comprehensive guidance and counseling program could not be measured because it was only about the development stage of the program model. The evaluation of the model was still prototype, so there are still opportunities for further development.

\section{REFERENCES}

[1] W. S. Winkel and M. M. S. Hastuti, Bimbingan dan konseling di institusi pendidikan. Media Abadi, 2005.

[2] N. Scotia, "Comprehensive guidance and counseling program: student services series. compehensive guidance and counseling program," 2007.

[3] B. and Gall, Educational Research: An Introduction Fourth Edition. New York: Longman, 2008.

[4] Sugiyono, Metode Penelitian Kuantitatif, Kualitatif dan R\&D. Bandung: Alfabeta, 2012.

[5] J. Rex, "The South Carolina Comprehensive Developmental Guidance and Counseling Program Model," Columbia South Carolina Dep. Educ., 2008.

[6] Daryono, "Model Program Guidance and Counseling Comprehensive Senior High School.," J. Guid. Couns., 2014.

[7] A. S. C. Association, The Asca National Model: A Frame Work For School Counseling Program. Alexandria: VA : Author, 2005.

[8] N. C. Gysbers and P. Henderson, Developing and managing your school guidance and counseling program. John Wiley \& Sons, 2014.

[9] Depdiknas, Penataan Pendidikan Profesional Konselor dan Layanan Bimbingan dan Konseling Dalam Jalur Pendidikan Formal. Jakarta: Depdiknas, 2008,

[10] Yusuf, Syamsy \& Nurihsan, Juntika, Foundation of Guidance and Counseling . Bandung: PT. Remaja Rosdakarya, 2008. 